\title{
Effects of Copper on Germination and Seedling Growth of Radish (Raphanus sativus L.)
}

\author{
*K.Chitra \\ * Assistant Professor, Department of Botany, Bharathiar University, Coimbatore, Tamil Nadu. India.
}

\begin{abstract}
An attempt has been made to assess the response of radish under the influence of copper with special reference to seed germination and seedling growth. Copper was applied in the form of copper-chloride $\left(\mathrm{CdCl}_{2}\right.$ $\left.2.4 \mathrm{H}_{2} \mathrm{O}\right)$. Various concentrations of copper $(0,5,10,25,50,75$ and $100 \mathrm{mg} / \mathrm{l})$ were prepared and used for germination studies. It is evident from the results obtained that the increase in copper concentration affected all the growth parameters such as germination percentage, length of root and shoot, fresh weight of root and shoot, vigour index and tolerance index.
\end{abstract}

(Key words: Radish, Copper, Growth parameters.)

\section{Introduction}

The major environment problems crop out from waste disposable, either from water pollutants or air pollutants. Friberg et al.(1974) observed that these pollutants had high concentration of heavy metals. Heavy metals have been increasing in the environment form waste, agricultural runoff and mining activities. Many of these metals have direct bearing on various physiological and biochemical processes including in growth, photosynthesis, chlorophyll content, inhabitation of enzyme activities and degeneration of chloroplast and mitochondria. Heavy metal stress causes multiple direct and indirect effects on all physiological processes in plans. In investigation on the metal toxicity in plants, it is very difficult to distinguish between the primary effects and secondary changes (Woolhouse, 1983).Copper is one of the toxic heavy metals which have many deleterious biological effects (Nriagu, 1980). They are quite often used as alloys in electroplating, auto industries, as stabilizers in polyvinyl chloride (PVC), plastics and in batteries.Copper at higher concentrations in soil may impose health hazards to plants and animals. This promoted our interest to explore the effects of different concentrations of copper on germination and seeding growth of Raphanus sativus (L).

\section{Materials And Methods}

The germination was carried out as per top paper method recommended by International seed testing association (1976). Various concentration of copper chloride solution namely, 0, 5, 10, 25, 50, 75 and $100 \mathrm{mg} / 1$ were prepared and used for the germination studies. These seeds of Raphanus sativus were obtained from the Tamil Nadu Agricultural University, Agricultural Research Station, Paramakkudi. Healthy seeds were selected and surface sterilized with 0.1 per cent mercuric chloride solution for 2 minutes and washed thoroughly with tap water and then with distilled water.

Twenty seeds were evenly placed in each petridishes. They were irrigated uniformly by various concentrations of the copper chloride solution in the respective petridishes. One set was irrigated with distilled water (control). All the petridishes were kept under diffused light at room temperature $\left(28+2^{0} \mathrm{C}\right)$. Five replications were maintained for each concentration. The germination percentage was recovered. The emergence of radical was taken as a criterion for germination. Ten seedlings from each replicate was selected fro recording the morphometrical parameters such as length of root and shoot, fresh weight of root and shoot, vigour index and tolerance index. They were recorded on the $8^{\text {th }}$ day after germination.

\section{Results And Discussion}

It is evident from the Table 1. The germination percentage and vigour index in the control was found to be maximum and gradually decreased with the increase of copper chloride concentration.Tolerance index of radish seedling gradually decreased with the increase of copper chloride concentration. The reduction in germination percentage of radish may be attributed to the interference of copper ions which may inhibit seed germination by exerting deleterious effect on the activities of hydrolytic enzymes involved in the mobilization of major seed reservoirs (Dua and Sawhney, 1991). Similar observations were recorded by Kalita et al.(1993) while studying the effect of copper on Tritticum aestivum. The same pattern of response was noticed in the cases of Vigna unguiculata L. due to chromium treatment by Lalitha et al. (1999)

The morphological parameters such as root length and shoot length showed a decreasing trend with increases copper chloride concentration. This is in consonance with the earlier report of Lata (1998) while working on the effect of copper on Cucurbita seedlings. 
The fresh weight of radish seedlings showed a similar trend. The reduction in fresh weight due to copper treatment may be attributed to the decreased metabolic rate and reduce transport from the cotyledons, at the same time it may also due to the higher rate of leakage in the membrane permeability. This is in consonance with the earlier reports of (Kalita, et al., 1993) in the case of Triticum aestivum. Balashouri and Prameeladevi (1995) while working on the effect of zinc on vigna radiata and Sorghum bicolour. Similar observations were also recorded by Mahalakshmi and Vijayarengan, (2003) in three plant species. The present investigation reveals that the various concentration of copper has drastic effects on germination and early growth. The growth of the crop plants has been highly reduced at higher concentrations. The concentration above $100 \mathrm{mg} / 1 \mathrm{has}$ proved to be lethal to the crop.

\section{References}

[1]. Balashouri and Prameelavi, 1995, Effect of zinc on germination, growth, pigment content And phytomass of vigna radiata and sorghum bicolour. J.Ecobiol., 7 (2): $109-114$.

[2]. Dua, A.And K.Sawhney, 1991.Effect of chromium on activities of hydrolytic enzymes in germinating pea seeds. Environ, Exp. Bot., 31(2): 133-139.

[3]. Friberg, L., M.Pisacator, G.F. Norberg and T.Kjellstron, 1974.Copper occurrence, possible route,

[4]. International seed testing association, 1976. International rules for seed testing, Sci.Tech. 4:51-177.

[5]. Kalita, M.C. Prameeladevi and I.Bhattacharya, 1993.Effect of copper on seed germination, early seedlings growth and chlorophyll content of Triticum aestivum. Indian J. Plant Physiol., 36 (3): 189 - 190.

[6]. Lalith, N. Balasubramanian and S.Kalavathy, 1999.Impact of chromium of Vigna unguiculata (L). J. Swamy Bot. Soc. 16: 17-20

[7]. Lata, S.1988. Differential influenced of copper on growth of certain cucurbit seedlings treated after radical emergence. Indian J.Ecol., 15 (1) 7-10.

[8]. Mahalakshmi, G. And P.Vijayarengan, 2003.Effects of zinc on germinating seeds of three plant species. Nature Environ. Pollut. Tech., 2(1):117-119.

[9]. Nriagu, J.O. 1980.Toxicity and tolerance in the response of plants of metals, pp-245-300.In :O.L.Lange, P.S.Noble., L.B.Osmond and H.Ziegler (eds). Physiological plant ecology ill.Responses to the chemical and biological environment. M.H.Z Harward. (eds)Encyclopedia of plant Physiology, New Series, Vol. 12c, Springer Verlag, Berlin.

Table 1: Effect of copper on germination, growth, fresh weight, vigour index and tolerance index of Raphanus sativus L.

\begin{tabular}{|c|c|c|c|c|c|}
\hline $\begin{array}{c}\text { Copper } \\
\text { Concentration mg/1 }\end{array}$ & $\begin{array}{c}\text { Germination } \\
\text { Percentage }\end{array}$ & $\begin{array}{c}\text { Root Length } \\
(\mathbf{c m})\end{array}$ & $\begin{array}{c}\text { Shoot Length } \\
(\mathbf{c m})\end{array}$ & $\begin{array}{c}\text { Root fresh } \\
\text { Weight (g/plant) }\end{array}$ & $\begin{array}{c}\text { Shoot Fresh Weight } \\
(\mathbf{g} / \mathbf{p l a n t})\end{array}$ \\
\hline 0 & 96 & 6.4 & 5.7 & 1.87 & 2.70 \\
\hline 5 & 100 & 7.9 & 6.5 & 1.98 & 2.34 \\
\hline 10 & 82 & 5.3 & 5.1 & 1.78 & 2.10 \\
\hline 25 & 78 & 5.1 & 5.0 & 1.70 & 1.88 \\
\hline 50 & 70 & 4.8 & 4.3 & 1.67 & 1.81 \\
\hline 75 & 62 & 4.5 & 4.1 & 1.62 & 1.75 \\
\hline 100 & 48 & 4.2 & 3.8 & 1.54 & 1.68 \\
\hline
\end{tabular}

(Percentage over control values are given in parentheses) 